\title{
Analysis of Hagemonic Practices in the Application of Occupational Health and Safety at Production Units in Pt. Aneka Tambang, TBK UBPN Pomalaa, Southeast Sulawesi
}

Anas

Hamka Naping

Husain Syam

Arlin Adam

\author{
Sociology Department of Universitas Negeri Makassar \\ Jln. Bonto Langkasa Kampus Gunung Sari Baru, South Sulawesi, Indonesia \\ Email:muhanas867@gmail.com, hamka.naping@yahoo.com,arlin_adam@yahoo.com
}

Doi:10.5901/mjss.2016.v7n6p243

\section{Abstract}

\begin{abstract}
One of the factors causing conflict between workers and the company are unsafe working conditions due to the application of the Occupational Health and Safety is not running properly. The research problem is: "How the application of Occupational Health and Safety at production unit in PT. Antam Tbk UBPN Pomalaa and forms of hegemony practices carried by the company for the benefit of workers hegemonic." Theoretically the Occupational Health and Safety system was made to protect workers. Gramci's theory of hegemony is used to identify the non-coercive repression that occured in PT. Antam Pomalaa. The research method used is qualitative critical emancipatory. The results showed the hegemony of the practices in PT Antam Tbk UBPN Pomalaa namely: (1) The pressure on workers in the form of inhibition of the employee's career (Pressure on carrier) (2) Creation of internal trade union PerAntam. PerAntam is a rival union SPSI (Dis-cohesion Internal). (3) Efforts to construct reasoning employees that Occupational Health and Safety is not less important than the welfare and advancement. (Construction of Reason). (4) The provision of facilities and infrastructure Occupational Health and Safety which do not have the required quality (Abandonment). The argument of this study is a hegemonic social relationship will be lasting if and only if it started from an attempt hegemony through the construction of reason, internal dis-cohesion and pressure on what is considered important by subordinate groups.
\end{abstract}

Keywords: Occupational Health and Safety, Hegemony, Critical Theory.

\section{Introduction}

\subsection{Background}

One of the factors causing conflict between workers and the company are unsafe working conditions due to the application of the Occupational Health and Safety is not running properly. These conditions led to a wave of looping accidents. Some literature suggests that facts cannot be ignored on the relationship less maximum implementation of Occupational Health and Safety with what was suffered by workers.

Heinrich in Winarsunu $(2008$, p. 7) reported that accidents caused by $88 \%$ due to the unsafe acts of persons, $10 \%$ by unsafe condition and $2 \%$ by other causes that cannot be learned. In his theory states that accidents are determined by five factors of first order is the social environment (social environment), both are traits not good (undesirable traits), the third is the act of a dangerous condition (unsafe act and condition hazard), the fourth is scene of an accident (accident), and a fifth was wounded (injury).

Preliminary observations of the study sites showed the facts told by an employee (Mr. Md) showed that the "procedures of K3 at PT Antam is there still some that has not been implemented and is not in accordance with the rules, such as: APD standards Fulfilment, the provision of safety equipment and a lack of signs or safety symbols. "

The above facts demonstrate the process of hegemony derived from unbalanced industrial relations. The practice of hegemony is the effort being made such that a suppression process goes unnoticed by the above groups. Practice hegemony is the main issue which is the starting point in this study, particularly in the PT Antam Pomalaa. 


\subsection{Problem Formulation}

The problems of research hegemonic process that occurs in PT Antam Pomalaa is as follows: "How is the implementation of Occupational Health and Safety (K3) at PT. Antam Tbk UBPN Pomalaa Production Unit and forms of hegemony practice that is conducted by the company for hegemonic interests to the workers".

\subsection{Objective}

The research objective of hegemonic processes that occur in the production unit PT Antam Pomalaa described as follows: "Analysing the implementation of Occupational Health and Safety (K3) at PT. Antam Tbk UBPN Pomalaa and practice forms of hegemony that is steered by the company to the hegemonic interests on workers.

\section{Literature Review}

This study makes several theories to be a knife of analysis in observing practices and forms of hegemony that happened at PT Antam Pomalaa. These theories include:

\subsection{The concept of Occupational Health and Safety (K3)}

Occupational Health and Safety (K3) is a key concept in this study. K3 can be described as a condition in the work of a healthy and safe both for the job, the company and for society and the environment around the factory or the workplace. Occupational health and safety is also an attempt to prevent any dangerous actions or conditions, which may lead to an accident.

Theoretically $\mathrm{K} 3$ is a system designed to protect workers that contains the answers to some of the points issue as expressed Whiting (2004, p. 14) as follows: (1) Are risk assessments performed by an individual or a team with the following skills; Practical knowledge of the operation being assessed? Knowledge of risk assessment techniques? Overview of other factors (such as operations) that may influence the risk? (2) Do a risk assessment training courses provide skills training to reduce perception biases? (3) Are the employees who are going to perform the operation involved in the risk assessment? (4) Is the accuracy of risk assessments performed by frontline employees monitored? (5) Was the way employees think about risk when risk assessments Considered processes, procedures, and documents were being designed? (6) Do a risk assessment procedures Ensure that specific task risk assessment is performed early enough to Ensure that sufficient time is available to implement the control measures and are not pressured to allow work to proceed? (7) Are task risk assessments performed by people who have the authority and resources required to implement additional risk control measures they feel are required? ) (8) Do risk communication campaigns address biases in risk perception in order to combat complacency about frequently performed operations?

These overall questions indicates the importance of knowledge, evaluation, supervision and communication between the company and employees in successful management of $\mathrm{K} 3$ and minimize workplace accidents and improve the health of its employees. Kadir A et al (2011, p. 19) stressed the need to audit the management of occupational safety and health (K3), as follows:

"Safety and health audit study is a part of occupational safety and health risk assessment. Tus, student's residential audits is important in order tu roomates Ensure the safety rules implemented by the management is Appropriate and follow the standards set forth. Furthermore, It also important to Determine places, area or situation that MIGHT lead to hazard risk prevention so that steps could be plan and implement ".

Therefore, the company is required to evaluate the management of $\mathrm{K} 3$ with the aim of increasing productivity and protecting employees from the growing opportunities for occupational safety and health issues at the company.

\subsection{Critical Theory and Theory of Hegemony of Antonio Gramsci}

Critical Theory selected as the main theoretical framework is because this theory telescoped social phenomenon in which there are unjust social relations. Unjust social reality is embodied in the existence of a social group experiencing systematic repression through the manipulation of knowledge about something. Parties were repressed soluble ideological framework dominant social groups so that they are not awakened at appropriate conditions. 
The essence of Critical Theory is not a theory that merely describing social reality but much more a thorough movement to change the unjust of social order. Breaking through further ahead the ideologically charged knowledge and dismantle it as something inserted in the minds of the subordinated people to be their social awareness. By doing dialectical relationship that is critical to the social reality, critical theory to seek a social movement that led to the awareness process on condition that is not fair in justice.

Critical Theory pioneered by figures from school of Frankfut from first generation (Hokheimer and Adorno) and second generation (Jurgen Habermas). Critical Theory provides a new direction for sociology. Despite the tendency of Marxism Critical Theory still exist but building distance from Classical Marxism.

Critical Theory states societies' knowledge is historical. In other words, the society's knowledge is the result of constructs that represent the interests of the dominant class. Knowledge that, once again, embodies an ideology in which the subordinate soluble therein. Critical theory seeks to dismantle the unfair process to uncover the reasons behind the interests of the company for not doing maximum efforts toward safety and health of its employees.

Hegemony theory can be classified philosophical contains elements of Critical Theory. Gramsci distinguishes two important terms of the mastery of one group against another group that is reference and hegemony. Kurniawan (2007, p. 3) describes the difference as follows:

"A class and its members exercise the power of the classes below it in two ways, namely violence and persuasion. How violence (repressive) carried on the lower class grade called the act of domination, while the means of persuasion called hegemony. This domination intermediary acts committed by the state apparatus such as the police, army and judges, while hegemony is in the form in still ideology to master classes or levels of society beneath"

The main idea of hegemony theory is a form of domination by non-coercive way. Simon in Pribadi $(2008$, p. 30) defines hegemony as a "series of domination over most aspects of human life, from economic, social, political, moral and intellectual up, with the advanced aspects noncorrosive -aspect consensual".

Hegemony has three phases, Simon and Salamini in Harjito $(2009$, p. 4) explain the phase of hegemony as follows: (1) the economic phase or negative phase, i.e materialistic territory, region inevitability, something inevitable human. This phase is an economic moment that raises awareness of the classes will be their political hegemony. The emergence of alternative history / historical rely heavily on the development of the means of production, for example, from manual to mechanical production methods. The process, it is not enough to change history. Changes in production methods is not in itself change the history, but it must be followed by a political phase. (2) Political Phase, the second phase, namely the relationship of political forces that enable the identification of various levels of homogeneity and political consciousness achieved by a group of potentially hegemonic (3) The third phase is the phase of hegemony or positive phase, namely the area of freedom, a process the creation of a new world view that equipping the masses with the categories of thought, behaviour, in the process of creating a new world view / world view. The positive phase is also called the phase of ideological hegemony. The elements of superstructure consciousness, ideology, culture is a factor that determines the nature, scope, and results of a revolution. Ideological hegemony can be defined as an organization of consciousness. It is distinguished by the dominance that is the arrangement of the material strength.

Counter hegemony is the way to form social movements are expected to occur within the community, including the relationship between PT Antam Tbk dominative UBPN Pomalaa with employees particularly related to implementation of Occupational Health and Safety (K3).

\subsection{Social Movement Theory}

Sustainability critical analysis narrows down to the effort on building social movement to dismantle and change hegemonic circumstances. McAdam (1982, p. 25) provides the definition of social movements as follows:

"Social movements are "Reviews those organized Efforts, on the part of excluded groups, to promote or resist changes in the structure of society that involve; noninstitutionalized recourse to forms of political participation."

Social movement has several requirements that must be there for the process towards the desired change can be manifested. Sunarto (2004) it has the characteristics as follows: (1) The social movement is the collective behavior (2) The social movements represent the collective interests (3) The social movement to change or maintain public or institutions that exist in nature (4) The social movement has a term long purpose (5) Social movements use means from outside the institution.

Social movements have a shape or type of variety. Korblum in Sunarto (2004) is divided into four social 
movements as follows: (1) Revolutionary Movement (Movement of Social Revolutionaries) is a kind of social movement that want profound changes in the very joints of people's existence, be it social system, cultural system, the economic system, as well as its political system. For example, Revolutionary Movements of Russian society in 1917 that managed to change the social system, cultural, economic, political and Russia into a communist system. Same thing happened in China in 1949. Both of these events are eligible revolution propounded by Antony Giddens, that a revolution; (A) involves a mass social movement, (b) results in a process of reform or change, and (c) use of threats and violence. (2) Reformative Movement (reformative social movement) is a social movement that wants changes to certain aspects of community life. Eg movement Boedi Utomo (1908) or Syarikat Islam (1912) who desire the fulfilment of the rights to education among natives. (3) Conservative Movement (Social Conservative Movement) is a social movement that maintains a state or institution in the society. For example, female conservative movement STOP ERA (Equal Rights Amendment). This movement opposed efforts by feminists in the 80 s to make changes to the constitution in order to ensure equal rights of men and women. (4) Reactionary Movement (Social Movement Reactionary) is a social movement that aims to change the institutions and values of today with the institutions and values of the past. The example given is a movement Kornblum Ku Klux Klan in the United States. This secret organization trying to restore the situation in the United States into the past at a time when social institutions support the superiority of whites over blacks Black (White Supremacy).

The social movement in demanding improvements in the management of occupational safety and health (K3) collectively Production Unit PT Antam Tbk UBPN Pomalaa is a form of social change, characterized by reformative. Feature reformative known for social change is just change certain things within a community, in this case the social groups that are in the region of PT Antam Tbk UBPN Pomalaa.

\subsection{Sociological Dimensions of Health and Safety at Work}

K3 management course can be analysed sociologically. Sociology Occupational Health and Safety (K3) is an effort to observe and analyse the K3 management by using a sociological viewpoint. This means the use of some of the sociological theory that can describe the condition of K3 management processes as much as possible, especially K3 management processes that make the implementation of K3 hegemony in PT Antam Pomalaa that not running optimally.

The first theory is the Critical Theory. The basic character of critical theory is very relevant when used to parse and undertake projects exemption to parties that harmed by the dominant group. Employees in relation to industrial relations with the company is a party that is often disadvantaged in the management of K3. Gramsci's theory of hegemony selection is one part of the Critical Theory to review covert non-coercive attempt to weaker parties.

The second theory is the theory of Social Action. All forms of social interaction will not run without a social action. Motive an action is the key to understanding the action carried out by the hegemony of the dominant group.

A third theory is the theory of Social Interaction. Rahayu (2010, p. 99) states that social interaction in society occurs in primary forms: (1) conversation cues (interaction non-symbolic) and (2) the use of important symbols (symbolic interaction). The relevance of this theory is to observe whether the forms of social interaction that exists between PT Antam Pomalaa by employees in relation to the management of K3.

The fourth theory is the Theory of Social Conflict. The theory of the conflict can be divided into two approaches namely structural Marxist and non-Marxist. Edward in Ismail (2012, p. 77) states that: "the social changes that may occur because of the factors in the social system itself (intra-systemic change), and the right approach to its approach is conflict approach (conflict approach), which in The next stage divided into two parts: (1) structuralize-Marxist; and (2) structuralize-non-Marxist. Structuralize approach-non-Marxist. Armed with the presuppositions as follows: (1) every society always in a process of change that never ends, in other words, social change is a social phenomenon that is always inherent in society; (2) every society is a source for the disintegration and social change; (4) integrated in every society on the control or domination by a number of people over a number of others, a theory which was originally developed by Marx. 


\subsection{Conceptual Framework}

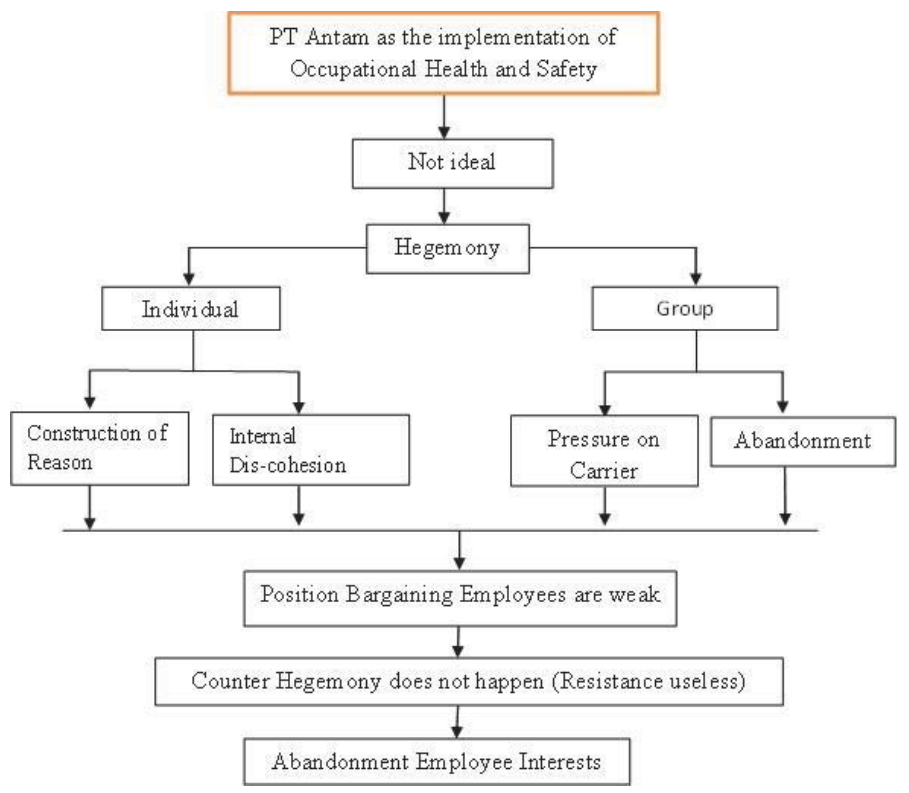

Figure 2.1: Conceptual Framework

Implementation of Occupational Health and Safety (K3) in the company are not running properly (not ideal) this states that the company PT Antam Tbk UBPN Pomalaa conducting hegemony process at every level which is individual and group level. At the individual level, PT Antam Tbk UBPN Pomalaa construction efforts of reason. Construction of reason is a strategy of influencing the minds of employees who do not to assume K3 issue is important. The next strategy is pressure on the carrier is an attempt to provide a threat to employees in the form of career hamper employee who deemed to fight that unwanted by company. At the group level, PT Antam Tbk UBPN Pomalaa pursuing an internal discohesion strategy of and negligence. Internal dis-cohesion is a strategy to break the employee power of social groups (unions). While negligence is the strategy where the employees demand were ignored. Four strategies will certainly weaken the bargaining position of employees that lead to employees' resistance do not achieve the outcomes for improving the condition of K3 Production Unit PT Antam Tbk UBPN Pomalaa. In other words, counter hegemony does not happen. That is the basis why the company neglecting employee demands.

\section{Methods}

The research method used, is a qualitative method of critical emancipatory. Neuman in Chariri $(2009$, p. 5) states that a more critical approach aims to fight the idea of researchers in order to bring substantial changes to the community. Research no longer produce scientific papers neutral / impartial and apolitical, but more of a tools to change social institutions, ways of thinking and people's behaviour towards to the directions that are believed to be better. Therefore, in this approach a deep understanding about a phenomenon based on the facts on the ground that needs to be complemented with an analysis and opinion based on researchers' personal circumstances, as long as sufficient arguments is provided. In brief, a critical approach is defined as a search for answers that go beyond the surface appearance are often dominated by the illusion, in order to help people to change their condition and shape their world for the better world.

The research location is at PT Antam Pomalaa Production Unit. Informants were selected based on purposive sampling technique. The selected sample is General Hospital and occupational health, general safety, unions and workers as well as related parties that are considered the most to know the ins and outs of planning and implementation of occupational safety and health program in PT. Antam Tbk UBPN Pomalaa Southeast Sulawesi. 
The data collection is done by (1) observation. The observations carried out in two stages. The first visit in November 2014 and the second observation was conducted in May 2015. The first phase generally identifies any issues regarding the implementation of K3 at PT Antam Tbk UBPN Pomalaa. The second phase, researchers conducted deepening to identify problems K3 in more detail and begin to identify employees who are considered to have a thorough knowledge of the problems of the implementation of K3 at PT Antam Tbk UBPN Pomalaa (2) in-depth interviews with 10 informants who are considered to have a very deep knowledge about the problems of K3 application at PT Antam Tbk UBPN Pomalaa. (3) Documentation is also done throughout the research process, it is done by either from documentation records of occupational accidents and in-depth interview process.

The data analysis of qualitative methods critical emancipatory by Comstock $(1980, p .8)$ states that " Critical social research begins from their real social problems experienced by a group of individuals, groups, or classes of oppressed and alienated from social processes growing and mounting. Starting from the practical problems of everyday life and this kind of research trying to resolve these issues through social action aimed at keeping the oppressed can liberate themselves from the shackles of oppression. Therefore, this study intersects with efforts to make society into the world of politics and raising their critics awareness. This dialogue method requires that the actors involved in this research process can cooperatively use their potential as active actors in creating history. Practically, this method requires that the researcher builds inter subjective relationship between researchers and the public that they can draw up an education program and action program that intended to change the oppressing social conditions. Analytically critical research should be able to create a dynamic relationship between the subjects within the social situations.

\section{Results and Discussion}

The results showed a picture informant statements that may be described in the table below:

Table 1. Informant Information mapping

\section{Informants Implementation of Occupational Behaviour company Post Work Safety and Health \\ Accident}

MO

The Company has conducted an The company takes a perfect steps obligation Occupational Safety and to improve post-accident conditions Health. Accidents occur due to human error

The Company has conducted an The company has taken the right obligation Occupational Safety and steps to improve the condition of Health. Accidents occur due to Occupational Safety and Health human error

The Company does not carry out its The Company does not undertake obligation to meet the standards of the maximum effort to improve the Occupational Safety and Health The company has been providing obligation Occupational Safety and APD and medical check-up Health but still there is a shortage adequate of safety

Is going according to the rules but less convenient to use APD

The Company has conducted a preventive measure but it lacks of health worker

Done by the rules. Accidents occur Already take preventive measures due to human error although limited to counselling alone and weak oversight

Is going according to the rules but The Company is not so serious in lower quality APD efforts to improve the quality of APD Is going according to the rules. The Less attention to the application of problem lies in the negligence individual accident the ideal conditions Occupational Safety and Health

Is going according to the rules but the equipment does not meet the standards

Good but not optimal in practice

Companies pay less attention to safety standards tool

The Company does not improve the condition of maximum Occupational Safety and Health

\section{Position Employee \& Strategy Employees Resistance}

Relatively weak, it is characterized by its employees focus on the issues that are not related to Occupational Safety and Health.

Employee bargaining position are weak and made little persuasive form of suggestion

Relatively weak and it seems workers and trade unions are not so concerned with the standard of Occupational Safety and Health relatively weak

Weak and employees do not dare to demand due to pressure from companies

Weak and exacerbated by disputes between unions

Weak and get threats with pressure from the company

Relatively weak though every scene of the accident made demands

Doing demands when the accident occurred, but the employee's position is relatively weak.

Dekohesivitas between unions led to resistance was not optimal. Moreover, there is pressure in the form of inhibiting careers of employees who tried to raise the

escalation of resistance.
Dominating Relation

Company against Employee

There was dominating relations

There were dominative relations

There were dominative relations

There were dominative relations

There were dominative relations

There were dominative relations

There were dominative relations

There were dominative relations

There were dominative relations

There was dominative relations 
The results showed the existence of hegemony conducted by the company in connection with the implementation of K3 at PT Antam Tbk UBPN Pomalaa. Various aspects can be seen in identifying porose hegemony by using critical reasoning. Some of the main points shows the process of hegemony is as follows: (1) Aspects of Historical, Statement informant about the demands and protests delivered repeatedly signalled their efforts within a certain timeframe pressing and creating resistance to companies hegemony (2) the presence of false awareness, research results shows that ignorance and neglect of workers on $\mathrm{K} 3$ related issues shows their false consciousness which is the result of inadequate understanding and deflection or falsification of reality by the hegemony party. (3) the emancipatory efforts by researchers. The process of awakening to the informant has been done by me where the stages of awareness can be described as follows: (a) provide an understanding personally to the informant (b) gives incentives to the workers through unions developing systematic resistance efforts (c) Researchers steering Focus Group Discussion (FGD) to the informant to provide awareness of the nature of K3.

The findings show the hegemony of the practices by the company PT Antam Tbk UBPN Pomalaa consists of: (1) The pressure on workers for them to not to take any excessive resistance in the form of inhibition of the employee's career (Pressure on the carrier). (2) Creation of internal trade union which is a rival of the union SPSI PT Antam Tbk UBPN Pomalaa namely PerAntam (Diskohesi Internal). (3) Efforts to construct reasoning employees that K3 is not less important than the issue of welfare and career advancement. (Construction of Reason). (4) The provision of K3 facilities and infrastructure which do not have the required quality (Neglect)

Fourth forms of hegemony over independent from each other. Hegemony begins on changing the employee structure of knowledge who cause K3 problems not made a priority by the employees. Misdirection of thought can be seen in most of the information the informant who firmly stated that the K3 not be the main priority. Until when the company provides quality PPE, and it's taken for granted.

The inadequate conditions of K3 will increase the potential industrial conflict. Companies must understand well the potential conflict can be manifest if the issue $\mathrm{K} 3$ allowed to drag on. Until these studies are completed, researchers did not find the company made maximum efforts to meet employee demands, especially regarding with APD.

An equitable social relation is a social relationship where all groups are treated equally. When one group of people act wants to dominate and act unjustly, community conflict is inevitable. The consequence of the unjust social relations is a process of contestation which will lead to the existence of other groups that will control one social group to another. When this domination process is steered with a subtly manner it is called hegemony.

Gramsci offers a way as resistance efforts against the unjust social system. Gramsci offers a road block of solidarity that rests on organic intellectual. Furthermore, Suhariyadi (2009, p. 200) describes the Gramscian strategy as follows:

\begin{abstract}
"Gramsci offered their solidarity bloc against the fascist regime. The mechanism is to mobilize the widest possible emergence of an intellectual force who has the vision and attitude in favour of freedom. Here Gramsci distinguish two intellectual complexions. The first, known as the traditional intellectual, the intellectual submissive and obedient to the interests of the fascist rule regime. Truthfully, such intellectual is public enemy because of the position and integrity of their collaboration with the regime and manipulating the political and social system that being oppressed already. The second, known as the intellectual organic, i.e. intellectuals (philosophers) came down from the "throne ivory tower" and joining with the community to carry out the professional task as well as raise public awareness of being manipulated by hegemonic forces by providing cultural educations and daily political language. They have served to strengthen the position of civil society (civil society) for accumulating the power of solidarity block, where people are aware of the political and social conditions and struggles to legitimize fascist power"
\end{abstract}

Resistance is absolutely necessary to make the circle of oppression can be deleted upon and through intellectual awareness of what is called by Marx as false consciousness is destructible. What was described by Gramsci on organic intellectual in tune with the views of Marx when describing the intellectuals who actually has become the oppressor puppet. Although Gramsci did not agree on Marx's assumption that economic factor as the basis of any form of social change, but Gramsci still take Marx's view that is in align with his theoretical interest.

The above statement to the investigators revealed the fact that the strategy undertaken by the employees which is the persuasive method is appropriate to ask and urge companies to change company policies related to K3 utilization considered by the employees have fundamental weaknesses. Persuasive strategy though until these study is completed, it does not show any adequate results as desired, but at least the dominant parties have realized that there is pressure to improve any weaknesses on K3 utilization.

The findings of research on the process and form of hegemony in PT Antam Pomalaa in the context of the management of $\mathrm{K} 3$ can be shown in the table below: 
Table 2. Forms and Hegemony Strategies

\author{
Form of Hegemony \\ Efforts to construct employees' reasoning that K3 is less important than the issue of welfare \\ and career advancement \\ The pressure on workers not to commit acts of excessive resistance \\ Creation of internal labor union which is a rival of the labor union SPSI PT Antam Pomalaa \\ The K3 infrastructure and facility provisions that do not have employees desired quality
}

\author{
Strategy of Hegemony \\ Construction of Reason (Individual Level) \\ Pressure on Carrier (Individual Level) \\ Internal Dis-Cohesion (Level Group) \\ Neglecting (Level Group)
}

The study's findings then abstracted by building a proposition that cannot be separated from the connectedness between variables as described above, as follows: (1) A process of hegemony lasted through the unequal relationship between social groups in society, including in industrial relations. (2) Industrial relations are imbalanced undoubtedly form the dominant classes who have the resources and the power to impose its interests and make subordinate groups do not have the ability to rally and mobilizing broad support. (3) The imposition of interest in dominative relation crossed in a subtle way to do falsification of reality that will shape the false consciousness that internal consolidation of blunt subordinate group or at least slowing down to cause of social resistance are difficult to achieve. (4) the false consciousness that is formed is a process of hegemony in which the goal is an attempt not to show the reality as what it is, that in the end subordinate groups will not able to go out and even consider that the oppressor party as the truthful party. (5) The dominant hegemonic party is a group that has a systematic plan to make the strength and stability of power can be sustained. Layered strategy is built as an anticipatory measure when a false consciousness successfully dismantled and realised and also able to trigger a systematic and mass resistance. (6) layered strategy is a strategy of nonphysical violent where its steps are faking the reality. Falsification of reality or the creation of false consciousness to be lined by breaking the power of subordinate groups internally by forming a rival institution in internal level (internal discohesion). (7) If both strategies namely the construction of reason in false consciousness and internal dis-cohesion resolved by subordinate groups then the final step is putting pressure on the important people in subordinate groups with various shape when the context of industrial relations can be done by inhibiting career even more it can end with dismissal.

Based on the description above, proposition developed that the researchers establish research proposition as follows: "A hegemonic social relation will last if and only it started from an attempt hegemony through the construction of reason, internal dis-cohesion and pressure on what is considered important by subordinate groups". This proposition, considered by researchers to be a proposition that has a high value of information with particularly regarding to the industrial relations context are imbalanced between the company and its employees. Nevertheless, researchers consider this proposition could be applied to all forms of social relations are shaped in the form of social dominative relations. Proposition found this is the expansion of Gramsci's theory with little to do variations not only include the effort on construction of ideas and knowledge in subordinate groups but also combining the so-called transition between noncoercive measures with coercive measures that the emphasis in the form of threats.

\section{Conclusion}

The conclusions in this study is the execution of Health and Safety (K3) implementation although qualifying procedural requirements however the quality of PPE is not qualified. The forms of hegemony in PT. Antam Tbk UBPN Pomalaa is Reasoning Construction, Pressure on Carrier, Internal Dis-cohesion and Neglect.

Troubled K3 Application indicates that systematically subordinated process which contain an attempt to deflect critical awareness subordinated parties. Non-coercive process is executed systematically that begins with a distorted understanding of the problematic conditions as not too problematic. The initial process will continue with efforts to divide the internal strength of the workers so that the resistance of concern arise can be anticipated from the beginning. If the escalation of resistance enlarges the pressure to the influencing figures that are considered the driving will, steered with efforts to put pressure and threats in forms of career inhibition to dismissal. When the scale of the resistance does not enlarge it means the company has the power to dismiss some of the charges are considered to be detrimental to the company without fear of any significant resistance from the employees.

\section{References}

Chariri, Anis. (2009). Landasan Filsafat dan Metode Penelitian Kualitatif. Workshop Metodologi Penelitian Kuantitatif dan Kualitatif, Laboratorium Pengembangan Akuntansi (LPA), Fakultas Ekonomi Universitas Diponegoro Semarang, 31 Juli -1 Agustus 2009. 
Comstock, Donald E. (1980). A Method for Critical Research. Washinton. The Red Feather Institute for Advanced Studies in Sociology. Harjito. (2009). Hegemoni Gramsci. Majalah IImiah Lontar. 23 (4), pp. 1-10.

Ismail. (2012). Penggabungan Teori Konflik Strukturalist-Non-Marxis dan Teori Fungsionalisme Struktural-Talcott Parsons Upaya Menemukan Model Teori Sosial Politik Alternatif Sebagai Resolusi Konflik Politik dan Tindak Kekerasan di Indonesia. Esensia. XIII (1), pp. 65-84.

Kadir A et.al. Kajian Audit Keselamatan dan Kesehatan Pekerjaan Terhadap Aspek Fizikal di Kolej Kediaman Dato' Onn, UKM. Journal of Community Health. Vol 17(1), pp. 9-17.

Kurniawan, Heru. (2007). Relasi Formatif Hegemoni Gramsci dalam Novel Perburuan Karya Pramoedya Ananta Toer. Ibda. 5 (1), pp. 157-175.

McAdam, Doug. (1982). Political Process and the Development of Black Insurgency 1930-1970. Chicago. University of Chicago Press.

Rahayu, Nuryani Tri. (2010). Teori Interaksi Simbolik dalam Kajian Komunikasi. Jurnal Widyatama. Vol. 9 (1), pp. 99-107.

Suhariyadi. (2009). Apikasi Teori Antonio Gramsci dalam Kajian Sosiologi Sastra Terhadap Novel Arok Dedes Karya Pramudya Ananta Toer. Prospektus, VII (2), pp. 197-204

Sunarto, Kamanto. (2004). Pengantar Sosiologi. Jakarta. Fakultas Ekonomi Universitas Indonesia.

Whiting, James F. (2004). The Missing Element of OHSMS and Safety Programmes - Calculating and Evaluating Risk.Journal Occupational Safety and Health. 1(1), pp. 9 -2

Winarsunu. (2008). Psikologi Keselamatan kerja. Universitas Muhammadyah Malang. Malang. 
ISSN 2039-2117 (online)

ISSN 2039-9340 (print)
Mediterranean Journal of Social Sciences MCSER Publishing, Rome-Italy
Vol 7 No 6 November 2016 